\title{
PHARMACOKINETICS OF FLUCONAZOLE IN LOGGERHEAD SEA TURTLES (CARETTA CARETTA) AFTER SINGLE INTRAVENOUS AND SUBCUTANEOUS INJECTIONS, AND MULTIPLE SUBCUTANEOUS INJECTIONS
}

\author{
Kate M. Mallo, B.S., Craig A. Harms, D.V.M., Ph.D., Gregory A. Lewbart, M.S., V.M.D., and \\ Mark G. Papich, D.V.M., M.S.
}

\begin{abstract}
Superficial and systemic mycotic infections are common among clinically ill sea turtles, which places growing importance on the establishment of pharmacokinetic-based dosage regimens for antifungal drugs. The pharmacokinetic properties of the antifungal drug fluconazole, after intravenous (i.v.) and subcutaneous (s.c.) injections, were studied in juvenile loggerhead sea turtles (Caretta caretta) housed at $23.0-26.5^{\circ} \mathrm{C}$. Fluconazole pharmacokinetic properties were further assessed in a multiple-dose s.c. regimen derived from the pharmacokinetic parameters determined in the single-dose study. Pharmacokinetic parameters were calculated, using a two-compartment model, from plasma concentration-time data obtained after single i.v. and s.c. administrations of fluconazole at a dosage of $2.5 \mathrm{mg} /$ $\mathrm{kg}$ body weight in six juvenile sea turtles. Blood samples were collected at intervals through $120 \mathrm{hr}$ after each dose, and the concentration of fluconazole in plasma was measured by reverse-phase high-performance liquid chromatography. The i.v. and s.c. elimination half-lives were $139.5 \pm 36.0$ and $132.6 \pm 48.7 \mathrm{hr}$ (mean \pm SD), respectively. Systemic clearance of fluconazole was $8.2 \pm 4.3 \mathrm{ml} / \mathrm{kg} \cdot \mathrm{hr}$, and the apparent volume of distribution at steady state was $1.38 \pm 0.29 \mathrm{~L} / \mathrm{kg}$. A multiple-dose regimen was derived, which consisted of a loading dose of $21 \mathrm{mg} / \mathrm{kg}$ body weight and subsequent doses of $10 \mathrm{mg} / \mathrm{kg}$ administered through s.c. injection every $120 \mathrm{hr}$ (5 days). This regimen was administered to four juvenile sea turtles for 10 days, and blood samples were taken to determine peak and trough plasma concentrations of fluconazole. The mean concentrations for the two peak concentrations were $16.9 \pm 1.1$ and $19.1 \pm 2.8 \mu \mathrm{g} / \mathrm{ml} 4 \mathrm{hr}$ after dosing, and the mean concentrations for the three trough concentrations were $7.2 \pm 2.2$, $10.4 \pm 2.7$, and $10.7 \pm 2.9 \mu \mathrm{g} / \mathrm{ml} 120 \mathrm{hr}$ after dosing. The terminal half-life after the last dose was calculated at 143 hr. Throughout the multiple dosing, fluconazole concentrations remained above approximately $8 \mu \mathrm{g} / \mathrm{ml}$, a concentration targeted when treating mycotic infections in humans. The results of this study suggest that fluconazole can be effectively administered to sea turtles at a dosage of $10 \mathrm{mg} / \mathrm{kg}$ every 5 days after a loading dose of $21 \mathrm{mg} / \mathrm{kg}$.
\end{abstract}

Key words: Fluconazole, sea turtle, Caretta caretta, pharmacokinetics, antifungal, fungal infection.

\section{INTRODUCTION}

Although mycotic infections are commonly encountered in clinically ill sea turtles, ${ }^{13,21}$ safe and effective dosage regimens for sea turtles have yet to be established for many antifungal agents. Although dosages for sea turtles are often extrapolated from those used in avian species and other reptiles, ${ }^{5,17}$ differences in disposition and clearance of antifungals between these species may result in altered safety and efficacy.

Fluconazole is a bis-triazole antifungal agent and is available as an oral or intravenous preparation. Like most other azole antifungals, fluconazole is fungistatic by inhibiting 14-alpha-demethylase, an enzyme that aids in the synthesis of ergosterol, a

From the Environmental Medicine Consortium and College of Veterinary Medicine, North Carolina State University, 4700 Hillsborough Street, Raleigh, North Carolina 27606, USA (Mallo, Lewbart, Papich); and the Center for Marine Sciences and Technology, 303 College Circle, Morehead City, North Carolina 28557, USA (Harms). Correspondence should be directed to Dr. Mallo. Address reprint requests to Dr. Harms. fungal cell membrane sterol. Fluconazole offers flexibility in its route of administration, has a low frequency of adverse effects, and has shown good tissue penetration because of its solubility profile. ${ }^{15}$ Fluconazole has activity against a broad range of fungi, including Blastomyces, Candida, Coccidioides, Cryptococcus, Histoplasma, and Aspergillus. ${ }^{7,10}$ In order to establish an effective dosing strategy for an antifungal agent in sea turtles, we examined the pharmacokinetics of fluconazole after single intravenous (i.v.) and subcutaneous (s.c.) injections in juvenile loggerhead sea turtles (Caretta caretta). Using the parameters determined from the single-dose phase of the study, a multiple-dose s.c. regimen was then derived and tested.

\section{MATERIALS AND METHODS}

\section{Subjects}

Single-dose phase: Six juvenile (2 to $4 \mathrm{yr}$ old) loggerhead sea turtles were used in the single-dose phase of the study. Each subject was examined and weighed before the study. Records indicated a steady weight gain on a diet of squid and mullet for the four largest turtles and a gel food prepara- 
tion (for sea turtles) combined with squid for the two smallest turtles. The weights of the subjects were as follows: $0.48,0.52,1.54,1.60,11.7$, and $12.2 \mathrm{~kg}$. The turtles were kept in individual aquariums, arranged by turtle size in three groups of two, ranging in capacity from 150 to $680 \mathrm{~L}(40-180$ gal). Two of the three groups were connected by a recirculating system filtered mechanically $(50 \mu \mathrm{m})$, whereas the third group was connected by a recirculating system filtered mechanically $(50 \mu \mathrm{m})$ and with activated carbon. The water in each tank was a mixture of tap water and artificial sea salts (Forty Fathoms Crystal Sea, Marine Enterprises International, Inc., Baltimore, Maryland 21221, USA). The salinity and $\mathrm{pH}$ in the tanks during week 1 ranged from 24 to 28 parts per thousand (ppt) and from 7.6 to 8.2 , respectively, and for week 2 from 31 to $34.5 \mathrm{ppt}$ and 7.7 to 8.0 , respectively. The temperatures of the aquariums ranged from $23.0^{\circ} \mathrm{C}$ to $26.5^{\circ} \mathrm{C}$.

Multiple-dose phase: Four juvenile (2 yr old) loggerhead sea turtles were used in the multipledose phase. Each subject was weighed and examined before the study. Each turtle was fed a gel food preparation combined with squid on a daily basis. The weights of the four turtles were 578, 799, 955, and $999 \mathrm{~g}$. The turtles were kept in individual aquariums in approximately $150 \mathrm{~L}$ of artificial seawater as stated previously. The four turtles were connected by a recirculating system that was filtered mechanically. The temperatures of the aquariums ranged from $23.0^{\circ} \mathrm{C}$ to $26.0^{\circ} \mathrm{C}$, and the salinity and the $\mathrm{pH}$, measured once, were $30 \mathrm{ppt}$ and 7.8 , respectively.

\section{Study design}

Single-dose phase: A two-period crossover design was used. Six turtles were used in the study, with three turtles receiving the i.v. treatment and three turtles receiving the s.c. treatment. After a 2wk washout period the two treatment groups were reversed and the experiment repeated. The i.v. treatment group in the first period consisted of turtles weighing $0.52,1.60$, and $11.7 \mathrm{~kg}$, whereas the s.c. treatment group consisted of turtles weighing $0.48,1.54$, and $12.2 \mathrm{~kg}$. This division of subjects was intended to ensure an even distribution of weights among the treatment groups for period 1 and period 2. Each animal received a single dose of $2.5 \mathrm{mg} / \mathrm{kg}$ body weight of fluconazole (Diflucan ${ }^{\circledR}$, Roerig Division, Pfizer Inc., New York, New York 10017, USA; $2 \mathrm{mg} / \mathrm{ml}$ in sodium chloride diluent) using a 23-ga needle. This initial dose was based on preliminary data obtained from a clinical case of fungal osteomyelitis in a Kemp's ridley sea turtle (Lepidochelys kempi). Intravenous injections were administered into the left dorsal cervical sinus, and s.c. injections were administered cranial to the left shoulder.

Blood collection alternated between the right and left dorsal cervical sinuses 0 (preadministration sample), $0.5,1.5,3,6,12,24,48,72$, and $120 \mathrm{hr}$ after injection. At each sampling, $0.5 \mathrm{ml}$ of blood was collected into a heparinized syringe using a 23-25-ga needle. The blood was centrifuged immediately, and the plasma was harvested and placed into plastic freezer vials. All plasma samples were stored at $-80^{\circ} \mathrm{C}$ for less than 4 wk until analysis.

Multiple-dose phase: Pharmacokinetic estimates from the single-dose study were used to derive a multiple-dose regimen. The regimen was designed using the published equations ${ }^{9}$ and a computer simulation program (WinNonlin Version 3.1, Pharsight Corp., Mountain View, California 94040, USA). Input into the simulation was based on the distribution and elimination rate constants of fluconazole obtained from the single-dose study. The regimen was calculated to provide an initial loading dose $\left(D_{L}\right)$ followed by a maintenance dose $\left(D_{M}\right)$ that would maintain the fluconazole plasma concentration above the target level of $8.0 \mu \mathrm{g} / \mathrm{ml}$ during the dosing interval. The regimen was optimized to allow for a long dose interval of 5 days.

All four sea turtles were placed in a single study group. Each turtle was given an initial loading dose of $21 \mathrm{mg} / \mathrm{kg}$ body weight of fluconazole, through s.c. injection, on day 0 of the experiment. A maintenance dose of $10 \mathrm{mg} / \mathrm{kg}$ body weight of fluconazole was administered, through s.c. injection, on days 5 and 10 of the experiment. All injections were administered cranial to the shoulder, alternating between the right and left sides, using a 22 -ga needle.

Blood collection alternated between the right and left dorsal cervical sinuses. The blood was collected before the loading dose (blank sample) and before each maintenance dose to assess trough concentrations. Additional samples were collected $4 \mathrm{hr}$ after injection on days 0 and 10 of the experiment to assess peak concentrations. Lastly, the blood was collected on days 12 and 15 of the experiment to measure the terminal elimination of fluconazole after the administration of the last dose. The blood collection and processing were as described for the single-dose study.

\section{Fluconazole assay}

Equipment: Concentrations of fluconazole in plasma collected from both the single- and multi- 
ple-dose studies were analyzed and quantified using high-performance liquid chromatography (HPLC) with ultraviolet (UV) detection. The system consisted of a pump (Waters Model 600 Solvent Delivery System, Millipore Corp., Milford, Massachusetts 01757, USA), an automatic injector (Series 1100 Autosampler, Hewlett-Packard Co., Palo Alto, California 94304, USA), and a variable-wavelength UV detector (Series 1100 VWD, Hewlett-Packard Co.), set at $210 \mathrm{~nm}$. Computer software was used to record the data from the system (HPLC ChemStation, Hewlett-Packard Co.).

HPLC conditions: Fluconazole was eluted on a C-8 reverse-phase column (Zorbax RX-C8, MAC MOD Analytical, Inc., Chadds Ford, Pennsylvania 19317, USA; $4.6 \mathrm{~mm} \times 15 \mathrm{~cm}$ ) with an isocratic mobile phase of $70 \% 0.01 \mathrm{M}$ potassium phosphate monobasic buffer and 30\% acetonitrile at a flow rate of $1.0 \mathrm{ml} / \mathrm{min}$. Mobile-phase components were filtered and degassed before use. The mobile phase was sparged with helium throughout the analysis.

Stock solutions and calibration curves: Stock solutions of fluconazole were prepared at concentrations of $1.0 \mathrm{mg} / \mathrm{ml}$, dissolved in acetonitrile. These solutions were further diluted with mobile phase to obtain spiking solutions ranging in concentration from 10.0 to $600 \mu \mathrm{g} / \mathrm{ml}$. These solutions were used to spike blank sea-turtle plasma for quality control and calibration standards. The concentrations of the calibration standards ranged from 0.50 to $30.0 \mu \mathrm{g} /$ $\mathrm{ml}$. Calibration curves were plotted on a linear graph of concentration vs. response (absorbance units) using weighted least-squares regression. Using sea-turtle plasma, new calibration standards were prepared on each day of analysis. All calibration curves were linear with an $r^{2}$ value $>0.99$, and all calibration standards fell within $15 \%$ of their true concentration. The precision coefficient of variation was $6.3 \%, 1.6 \%$, and $1.0 \%$ at low, medium, and high concentrations, respectively. The accuracy of the assay was within $4.05 \%, 0.8 \%$, and $0.68 \%$ of the true concentration at low, medium, and high concentrations, respectively. Analysis of a blank plasma sample from each subject was performed to verify that there were no interfering peaks in the chromatogram. The lowest concentration on the linear calibration curve was $0.5 \mu \mathrm{g} / \mathrm{ml}$. All concentrations measured during the study were above this concentration; therefore, $0.5 \mu \mathrm{g} / \mathrm{ml}$ was defined as the lowest limit of quantification.

Sample preparation: Samples (quality control and collected samples) were prepared by first adding $100 \mu \mathrm{l}$ of a 1:4 mixture of acetonitrile-methanol to a microcentrifuge tube, followed by a 200$\mu l$ aliquot of each sample. The tubes were vortexed to precipitate protein from the sample. After the addition of $1.0 \mathrm{ml}$ of double-distilled water, the tubes were vortexed again and then centrifuged at $7.2 \times 10^{3} \mathrm{~g}$ for $4 \mathrm{~min}$. C18 Dual-Zone cartridges (Diazem Corp., MetaChem, Torrance, California 90503, USA) were inserted into a solid-phase extraction manifold and conditioned with $2.0 \mathrm{ml}$ $100 \%$ methanol followed by $2.0 \mathrm{ml}$ of distilled water. Solid-phase extraction was used to further clean the samples by vacuuming $(-12.7 \mathrm{~cm} \mathrm{Hg}) 500 \mu \mathrm{l}$ of the sample (or the standard) through a C18 DualZone cartridge, and supernatant from the samples was collected into $16-\times 100-\mathrm{mm}$ borosilicate tubes. The cartridges were washed with $2.0 \mathrm{ml}$ of double-distilled water and dried by applying the vacuum for $1 \mathrm{~min}$. The cartridges were eluted with $1.0 \mathrm{ml}$ of a 1:4 mixture of acetonitrile-methanol. The tubes containing the extracted samples (or standards) were heated $\left(45^{\circ} \mathrm{C}\right)$ for $20-25 \mathrm{~min}$ under nitrogen until the solvent was completely evaporated. Each sample was then reconstituted with 200 $\mu l$ of mobile phase, vortexed, and transferred to an HPLC injection vial for injection. The injection volume was $40 \mu \mathrm{l}$. The retention times for fluconazole ranged from 3.2 to $3.4 \mathrm{~min}$. The concentration of fluconazole in each sample was estimated from linear regression analysis using the calibration curve generated from the day's run.

Pharmacokinetic analysis: Plasma samples after i.v. drug administrations were plotted semilogarithmically for analysis. Analysis of curves was performed on a personal computer using a curvefitting program (WinNonlin Version 3.1). A twocompartment pharmacokinetic model was confirmed to be the best fit on the basis of a smaller value for the Akaike's information criterion. ${ }^{23}$ The two-compartment biexponential model was represented by this equation: $\mathrm{C}=\mathrm{Ae}^{-\alpha t}+\mathrm{Be}^{-\beta t}$, where $\mathrm{C}$ is the concentration at time $\mathrm{t}, \mathrm{A}$ and $\mathrm{B}$ are the $\mathrm{y}-$ axis intercepts for the distribution and elimination phases of the curve (Table 1), respectively, $\alpha$ and $\beta$ are the slopes of the distribution and elimination phases of the curve, respectively, and e is the base of the natural logarithm. A weighting factor $\mathrm{W}=$ $1 / \mathrm{Y}^{2}$ was used for the curve analysis, where $\mathrm{Y}$ is the plasma concentration of fluconazole. The elimination half-life $\left(t_{1 / 2}\right)$ was estimated from the following relationship: $t_{1 / 2}=\ln 0.5 / \beta$. Model-independent methods were used to calculate the area under the curve (AUC) from time 0 to infinity, the mean residence time (MRT), the apparent volumes of distribution, and the systemic clearance $\left(\mathrm{Cl}_{\mathrm{s}}\right)$. The area under the plasma concentration vs. time curve from time 0 to the last-measured concentration $\left(\mathrm{C}_{\mathrm{n}}\right)$ was calculated using the trapezoidal method. Model-in- 
Table 1. Mean ( \pm SD) pharmacokinetic values for intravenous and subcutaneous fluconazole in juvenile loggerhead sea turtles (Caretta caretta) after a single $2.5 \mathrm{mg} / \mathrm{kg}$ dose.

\begin{tabular}{lcc}
\hline \multicolumn{1}{c}{ Parameter $^{\mathrm{a}}$} & Intravenous & Subcutaneous \\
\hline $\mathrm{C}_{\mathrm{MAX}}(\mu \mathrm{g} / \mathrm{ml})$ & $2.7 \pm 0.5$ & $2.1 \pm 0.4$ \\
$\mathrm{t}_{1 / 2}(\mathrm{hr})$ & $132.6 \pm 48.7$ & $139.5 \pm 36.0$ \\
$\mathrm{AUC}_{\text {observed }}(\mu \mathrm{g} \cdot \mathrm{hr} / \mathrm{ml})$ & $166.7 \pm 47.1$ & $159.7 \pm 48.0$ \\
$\mathrm{AUC}_{\text {extrapolated }}(\mu \mathrm{g} \cdot \mathrm{hr} / \mathrm{ml})$ & $360.4 \pm 172.2$ & $368.7 \pm 177.5$ \\
$\mathrm{Alpha}(/ \mathrm{hr})$ & $0.8 \pm 0.32$ & \\
$\mathrm{Beta}(/ \mathrm{hr})$ & $0.0 \pm 0.00$ & \\
$\mathrm{Cl}_{\mathrm{s}}(\mathrm{ml} / \mathrm{kg} \cdot \mathrm{hr})$ & $8.2 \pm 4.3$ & \\
$\mathrm{AUMC}\left(\mu \mathrm{g} \cdot \mathrm{hr}{ }^{2} / \mathrm{ml}\right)$ & $83,195.8 \pm 84,407.2$ & $1995.1 \pm 59.137 .0$ \\
$\mathrm{MRT}(\mathrm{hr})$ & $190.1 \pm 71.1$ & \\
$\mathrm{Vd}_{\text {area }}(\mathrm{L} / \mathrm{kg})$ & $1.40 \pm 0.28$ & \\
$\mathrm{Vd}_{\mathrm{ss}}(\mathrm{L} / \mathrm{kg})$ & $1.38 \pm 0.26$ & \\
\hline
\end{tabular}

a Abbreviations: $\mathrm{C}_{\mathrm{MAX}}$, maximum plasma concentration; $\mathrm{t}_{1 / 2}$, elimination half-life; AUC, area under the curve; $\mathrm{Cl}_{\mathrm{s}}$, systemic clearance; AUMC, area under moment curve; MRT, mean residence time; $\mathrm{Vd}_{\text {area }}$, volume of distribution (area); $\mathrm{Vd}_{\mathrm{ss}}$, volume of distribution at steady state.

dependent methods were also used to determine the terminal $t_{1 / 2}$, the MRT, and the systemic availability $(\% \mathrm{~F})$ from the s.c. administration. Systemic availability was calculated from the following relationship: $\% \mathrm{~F}=\left(\mathrm{AUC}_{\mathrm{s} . \mathrm{c} .} / \mathrm{AUC}_{\mathrm{i} . \mathrm{v} .}\right) \times 100$. The values for the detected maximum plasma concentration $\left(\mathrm{C}_{\mathrm{MAX}}\right)$ and the time of maximum detected plasma concentration $\left(\mathrm{T}_{\mathrm{MAX}}\right)$ were the observed values. Statistical differences between routes of administration were measured by Student's $t$-test for independent samples (JMP, SAS Institute, Cary, North Carolina 27513, USA). The level of significance was $P<$ 0.05 .

\section{RESULTS}

\section{Single-dose phase}

The pharmacokinetic parameters derived from the single-dose study are given in Table 1 . Flucon- azole administration produced nearly identical plasma concentration profiles both by i.v. and by s.c. administration (Fig. 1). Examination of the $\mathrm{AUC}_{\text {s.c. }}$ ! $\mathrm{AUC}_{\mathrm{i} . \mathrm{v}}$ ratio in the single-dose study shows that s.c. absorption was complete. The calculated systemic availability $(\% \mathrm{~F})$ was $108 \%$. The $\mathrm{C}_{\mathrm{MAX}}$ for the s.c. group, $2.1 \pm 0.5 \mu \mathrm{g} / \mathrm{ml}$ (mean $\pm \mathrm{SD}$ ), was very close to that of the i.v. group, $2.7 \pm 0.5 \mu \mathrm{g} / \mathrm{ml}$. There were no statistically significant differences between routes of administration for the parameters $\mathrm{C}_{\mathrm{MAX}}, \mathrm{t}_{1 / 2}, \mathrm{AUC}$, and MRT. The mean $\mathrm{T}_{\mathrm{MAX}}$ for the s.c. group was $4.8 \mathrm{hr}$. The average $\mathrm{t}_{1 / 2}$ of the i.v. group was $132.5 \mathrm{hr}$, whereas the average $\mathrm{t}_{1 / 2}$ of the s.c. group was $139.5 \mathrm{hr}$.

\section{Multiple-dose phase}

The actual peak and trough concentrations of fluconazole measured while testing the multiple-dose

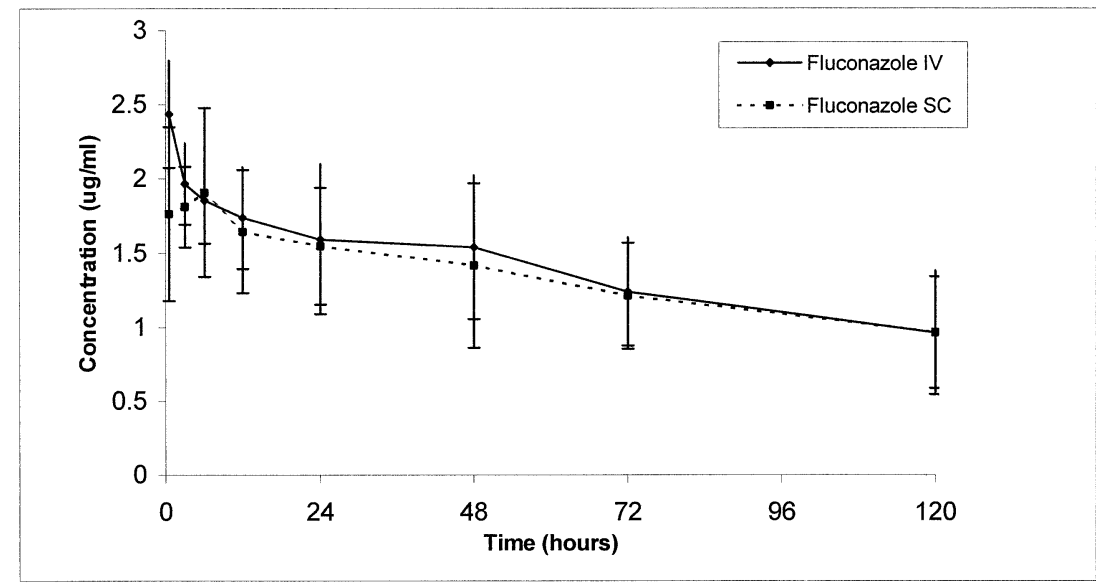

Figure 1. Mean $( \pm \mathrm{SD})$ fluconazole plasma concentration after i.v. and s.c. injection of $2.5 \mathrm{mg} / \mathrm{kg}$ in two groups of juvenile loggerhead sea turtles ( $n=6$ in each group). 


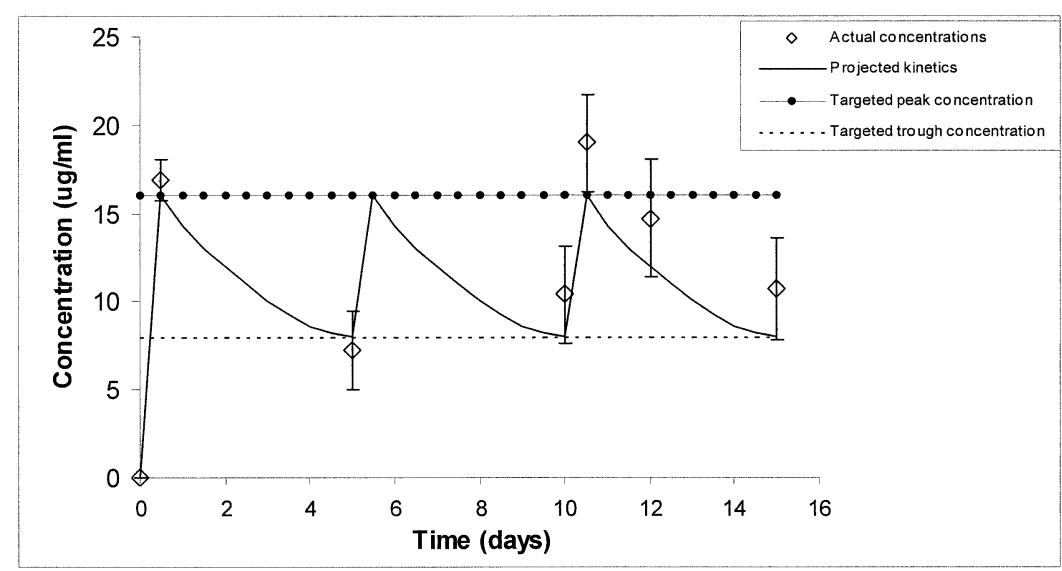

Figure 2. Projected kinetics of fluconazole and actual (mean \pm SD) concentrations measured after administering a loading dose of $21 \mathrm{mg} / \mathrm{kg}$ and two maintenance doses of $10 \mathrm{mg} / \mathrm{kg}$ every 5 days ( $n=4$ turtles).

regimen, along with the projected kinetics of the drug, are presented in Figure 2. Peak concentrations of fluconazole after a loading dose of $21 \mathrm{mg} / \mathrm{kg}$ s.c. and maintenance doses of $10 \mathrm{mg} / \mathrm{kg}$ s.c. q 5 days were $16.9 \pm 1.2 \mu \mathrm{g} / \mathrm{ml} 4 \mathrm{hr}$ after the day 0 injection and $19.0 \pm 2.8 \mu \mathrm{g} / \mathrm{ml} 4 \mathrm{hr}$ after the day 10 injection. Trough concentrations were as follows: $7.2 \pm$ $2.2 \mu \mathrm{g} / \mathrm{ml}, 120 \mathrm{hr}$ after the day 0 injection; $10.4 \pm$ $2.75 \mu \mathrm{g} / \mathrm{ml}, 120 \mathrm{hr}$ after the day 5 injection; and $10.7 \pm 2.9 \mu \mathrm{g} / \mathrm{ml}, 120 \mathrm{hr}$ after the day 10 injection. The terminal half-life was $143 \mathrm{hr}$.

\section{DISCUSSION}

This study indicates that fluconazole has a prolonged half-life in sea turtles as compared with the half-lives in cats, dogs, and humans (12-25, 15, and $\sim 30 \mathrm{hr}$, respectively). ${ }^{3,6,11,22}$ Kinetic parameters for both i.v. and s.c. administration show only minor differences and indicate excellent absorption after s.c. administration. This level of absorption can be attributed to fluconazole's high systemic availability and solubility profile. ${ }^{7}$ The calculated systemic availability after oral administration in humans has been reported to be $>90 \%$ and in cats, $109 \%$.,6

The volume of distribution of fluconazole in sea turtles is marginally higher than the ranges reported for i.v. and oral doses in cats $(1.0-1.1 \mathrm{~L} / \mathrm{kg})$, humans, dogs, rats, and mice $(0.7-1.1 \mathrm{~L} / \mathrm{kg}) .^{11,22} \mathrm{In}$ this study the volume of distribution of fluconazole was $1.38 \mathrm{~L} / \mathrm{kg}$ for i.v. administration. Because of the similarity in volumes of distribution across species, the remarkably long half-life in sea turtles found in this study can probably be attributed to differences in the clearance of fluconazole. The clearance rate of fluconazole in this study was 8.2 $\mathrm{ml} / \mathrm{kg} \cdot \mathrm{hr}$, which is much lower than the clearance values reported for dogs and humans, $36 \mathrm{ml} / \mathrm{kg} \cdot \mathrm{hr}$ and $24 \mathrm{ml} / \mathrm{kg} \cdot \mathrm{hr}$, respectively. ${ }^{11}$ The calculated clearance is dependent on $\mathrm{AUC}_{\text {extrapolated, }}$, which in this study includes a larger extrapolated portion than is preferable (approximately 50\%) because of the long half-life. The terminal portion of the curve, however, is sufficiently linear so that we feel the estimate of the extrapolated portion of the AUC to be accurate.

In rats, mice, dogs, and humans, fluconazole is eliminated primarily by the kidneys because of its structure and metabolic stability. ${ }^{7,11}$ Differences in fluconazole clearance between species are, in part, most likely because of differences in the glomerular filtration rate (GFR). The reported GFR of green sea turtles (Chelonia mydas) is approximately 0.24 $\mathrm{ml} / \mathrm{kg} \cdot \mathrm{min}$ ), whereas that of the $\operatorname{dog}$ is approximately $3.09 \mathrm{ml} / \mathrm{kg} \cdot \mathrm{min} .^{1,18}$ Fluconazole clearance by loggerhead sea turtles in this study $(0.137 \mathrm{ml} /$ $\mathrm{kg} \cdot \mathrm{min}, 8.2 \mathrm{ml} / \mathrm{kg} \cdot \mathrm{hr}$ ) was only $59 \%$ of the reported green sea turtle GFR $(0.24 \mathrm{ml} / \mathrm{kg} \cdot \mathrm{min}) .^{18}$ Differences between GFR and clearance for a renally excreted drug can be explained by plasma protein binding or by postfiltration reabsorption. The reported levels of plasma protein binding are negligible $(11-12 \%)$ in humans, ${ }^{4}$ and it is likely that a large proportion of fluconazole also circulates as unbound, free active drug in sea turtles. Postfiltration reabsorption could take place in the renal tubules or, in chelonians, in the urinary bladder, distal colon, or cloaca. ${ }^{2}$

The dosage used in the single-dose study was selected on the basis of preliminary results from a clinical case, which had indicated that fluconazole administered at $2.5 \mathrm{mg} / \mathrm{kg}$ s.c. q $24 \mathrm{hr}$ could result in a plasma concentration of $6.9-8.1 \mu \mathrm{g} / \mathrm{ml}$. How- 
ever, $\mathrm{C}_{\mathrm{MAX}}$ for s.c. administration in the single-dose study was only $2.1 \pm 0.5 \mu \mathrm{g} / \mathrm{ml}$. With once-daily dosing of $2.5 \mathrm{mg} / \mathrm{kg}$, the target plasma concentration of $8 \mu \mathrm{g} / \mathrm{ml}$ could be reached in approximately 30 days because of the prolonged half-life. Such a dosing regimen delays the attainment of steadystate therapeutic concentrations and requires more frequent dosing than does the multiple-dosing regimen tested.

Throughout the multiple-dose regimen, fluconazole concentrations in the plasma ranged from approximately 8 to $19 \mu \mathrm{g} / \mathrm{ml}$. This range is similar to the concentrations achieved in the treatments of mycotic infections in humans ${ }^{7}$ and of some pathogens (e.g., Aspergillus spp.) reported in sea turtles and other reptiles. ${ }^{8,13,20,21}$ Aspergillus spp. have been identified in lesions of dermal and superficial mycoses of young loggerheads and Kemp's ridleys. ${ }^{8}$ Aspergillus spp. have also been identified in systemic mycotic infections in reptiles, which often manifest as pulmonary and alimentary diseases. ${ }^{14,20}$ Although some in vitro studies report marginal efficacy of fluconazole against Aspergillus spp. at selected doses, ${ }^{12}$ in vivo performance is often better than would be predicted from in vitro findings. ${ }^{10}$ We were unable to locate fluconazole susceptibility data for other fungi reported in sea turtles (Paecilomyces spp., Sporotrichium spp., Cladosporium spp., Beauveria bassiana). ${ }^{8,13,21}$

The terminal half-life $(143 \mathrm{hr})$ in the multipledose phase was very close to the elimination halflife calculated for single s.c. administration (139.5 $\mathrm{hr}$ ), which indicates that multiple doses of fluconazole do not alter its systemic clearance through induction or inhibition of metabolic enzymes.

Previously reported or recommended doses of fluconazole for use in sea turtles and other reptiles ranged from $0.75 \mathrm{mg} / \mathrm{kg}$ s.c. q $48 \mathrm{hr}$ to $5 \mathrm{mg} / \mathrm{kg}$ p.o. q $24 \mathrm{hr} .^{5,21}$ Direct extrapolation from mammalian, avian, or even other reptilian species can result in doses that may not account for differences in metabolic rate, renal physiology, and water conservation. Metabolic scaling can also be problematic because application of a single allometric equation for reptiles is not considered valid. ${ }^{13}$ Furthermore, creating an allometric equation for even a single ectothermic species presents many challenges because of the effect of variations in body temperature. Although pharmacokinetic differences may exist between closely related species, ${ }^{13}$ data from pharmacokinetic studies in the same or in closely related species provide the best starting point for calculating dosage schedules. Pharmacokinetic studies in sea turtles are rare but include the study of ceftazidime in loggerhead sea turtles and a recent preliminary study of itraconazole in Kemp's ridleys. ${ }^{16,19}$ The present study provides the first report of pharmacokinetic data for fluconazole in healthy juvenile loggerhead sea turtles kept at $23.0-26.5^{\circ} \mathrm{C}$. Dosage modifications may need to be made in patients with renal impairment, dehydration, hypothermia, or other conditions because their effects on the pharmacokinetics have not been addressed in this study. Monitoring of clinical response to therapy and clinical pathology values, as well as focal sampling of peak and trough concentrations when possible, is advisable to assist in making adjustments in treatment.

Fluconazole is available in formulations for i.v. injection (in saline or dextrose diluents) or oral administration (tablets or oral suspension). This study examined the pharmacokinetics of i.v. and s.c. injection of the injectable formulation in saline diluent. The ability to deliver an effective concentration of an antifungal drug parenterally represents an attractive option for treating inappetent sea turtles. Administering the i.v. formulation in saline diluent by s.c. injection did not appear to be unduly irritating. The animals did not appear to favor the flipper on the side of the injections, and no local tissue reactions were observed. In addition to these observations, a juvenile Kemp's ridley on long-term $(>1 \mathrm{yr}$ ) fluconazole therapy (initially, $2.5 \mathrm{mg} / \mathrm{kg}$ s.c. q $24 \mathrm{hr}$, then switched to $10 \mathrm{mg} / \mathrm{kg}$ s.c. q 5 days on the basis of the current study) displayed no elevations in creatine kinase (Harms, unpubl. data). Gastrointestinal upset, as evidenced by diarrhea, nausea, and vomiting, is the most commonly observed adverse effect of fluconazole in mammals ${ }^{7}$; however, this effect was not observed in any of the subjects in this study.

The results of this study suggest that fluconazole can be effectively administered through s.c. injection to sea turtles at a dosage of $10 \mathrm{mg} / \mathrm{kg}$ body weight every 5 days after a single loading dose of $21 \mathrm{mg} / \mathrm{kg}$.

Acknowledgments: This study was conducted under an endangered species permit issued by the North Carolina Wildlife Resources Commission. Animal use was reviewed and approved by the North Carolina State University Institutional Animal Care and Use Committee. The authors thank Jay Barnes and the North Carolina Aquarium at Pine Knoll Shores; Jean Beasley and the Karen Beasley Sea Turtle Rescue and Rehabilitation Center; Ruth Boettcher and the North Carolina Wildlife Resources Commission; and the following individuals for their help in this study: Cristy Bleck, Elizabeth Chittick, Adrien Elliott, Bob Jones, Stuart 
May, Jeff McBane, Kristy McNeal, Delta Plummer, and Rick Schultz.

\section{LITERATURE CITED}

1. Bovee, K. C., and T. Joyce. 1979. Clinical evaluation of glomerular function: 24-hour creatinine clearance in dogs. J. Am. Vet. Med. Assoc. 174: 488-491.

2. Boyer, T. H., and D. M. Boyer. 1996. Turtles, tortoises, and terrapins. In: Mader, D. R. (ed.). Reptile Medicine and Surgery. W. B. Saunders Co., Philadelphia, Pennsylvania. Pp. 61-77.

3. Brammer, K. W., P. R. Farrow, and J. K. Faulkner. 1990. Pharmacokinetics and tissue penetration of fluconazole in humans. Rev. Infect. Dis. 12(3): 318-326.

4. Brammer, K. W., and M. H. Tarbit. 1987. A review of the pharmacokinetics of fluconazole (UK-49,858) in laboratory animals and man. In: Fromtling, R. A. (ed.). Recent Trends in the Discovery, Development, and Evaluation of Antifungal Agents. J. R. Prous Science Publishers SA, Barcelona, Spain. Pp. 141-150.

5. Carpenter, J. W., T. Y. Mashima, and D. J. Rupiper. 2001. Exotic Animal Formulary, 2nd ed. W. B. Saunders Co., Philadelphia, Pennsylvania. Pp. 41-105.

6. Craig, A. J., I. Ramzan, and R. Malik. 1994. Pharmacokinetics of fluconazole in cats after intravenous and oral administration. Res. Vet. Sci. 57: 372-376.

7. Debruyne, D., and J. P. Ryckelynck. 1993. Clinical pharmacokinetics of fluconazole. Clin. Pharmacokinet. 24: $10-27$.

8. George, R. H. 1997. Health problems and diseases of sea turtles. In: Lutz, P. L., and J. A. Musick (eds.). The Biology of Sea Turtles. CRC Press, Boca Raton, Florida. Pp. 363-385.

9. Gibaldi, M., and D. Perrier. 1982. Pharmacokinetics, 2nd ed. Marcel Dekker, New York.

10. Heit, M. C., and J. E. Riviere. 1995. Antifungal and antiviral drugs. In: Adams, H. R. (ed.) Veterinary Pharmacology and Therapeutics. Iowa State Univ. Press, Ames, Iowa. Pp. 855-883.

11. Humphrey, M. J., S. Jevons, and M. H. Tarbit. 1985. Pharmacokinetics evaluations of UK-49,858, a metabolically stable triazole antifungal drug, in animals and humans. Antimicrob. Agents Chemother. 28: 649-653.

12. Ikemoto, H., K. Watanabe, T. Mori, A. Taniuchi, Y. Akakonai, C. Mikuni, K. Yoshida, M. Kasai, K. Kawamura, and T. Yoshida. 1989. Clinical study of fluconazole on deep-seated fungal infections. Jpn. J. Antibiot. 42: 63116.
13. Jacobsen, E. R. 1999. Use of antimicrobial drugs in reptiles. In: Fowler, M. E., and R. E. Miller (eds.). Zoo and Wild Animal Medicine Current Therapy 4. W. B. Saunders Co., Philadelphia, Pennsylvania. Pp. 190-200.

14. Junge, R. E., and R. E. Miller. 1992. Reptile respiratory diseases. In: Kirk, R. W., and J. D. Bonagura (eds.). Current Veterinary Therapy XI. W. B. Saunders Co., Philadelphia, Pennsylvania. Pp. 1210-1213.

15. Kowalsky, S. F., and D. M. Dixon. 1991. Fluconazole: a new antifungal agent. Clin. Pharmacol. 10: 179194.

16. Manire, C. A., H. L. Rhinehart, G. J. Pennick, and M. G. Rinaldi. 2001. Plasma and tissue concentrations of itraconazole in the Kemp's ridley sea turtle (Lepidochelys kempi). Proc. Int. Assoc. Aquatic Anim. Med. 32: 167.

17. Murray, M. J. 1996. Pneumonia and normal respiratory function. In: Mader, D. R. (ed.). Reptile Medicine and Surgery. W. B. Saunders Co., Philadelphia, Pennsylvania. Pp. 396-405.

18. Schmidt-Nielson, B., and L. E. Davies. 1968. Fluid and tubular intercellular spaces in reptilian kidneys. Science 159: 1105-1108.

19. Stamper, M. A., M. G. Papich, G. A. Lewbart, S. B. May, D. D. Plummer, and M. K. Stoskopf. 1999. Pharmacokinetics of ceftazidime in loggerhead sea turtles (Caretta caretta) after single intravenous and intramuscular injections. J. Zoo Wildl. Med. 30: 32-35.

20. Tappe, J., F. Chandler, S. Lui, and E. Dolensek. 1984. Aspergillosis in two San Esteban chuckwallas. J. Am. Vet. Med. Assoc. 185(11): 1425.

21. Turnbull, B. S., C. R. Smith, and M. A. Stamper. 2000. Medical implications of hypothermia in threatened loggerhead (Caretta caretta) and endangered Kemp's ridley (Lepidochelys kempi) and green (Chelonia mydas) sea turtles. Proc. Am. Assoc. Zoo Vet./Int. Assoc. Aquatic Anim. Med. Joint Conf. 31-36.

22. Vaden, S. L., M. C. Heit, E. C. Hawkins, C. Manaugh, and J. E. Riviere. 1997. Fluconazole in cats: pharmacokinetics following intravenous and oral administration and penetration into cerebrospinal fluid, aqueous humour, and pulmonary epithelial lining fluid. J. Vet. Pharmacol. Ther. 20: 181-186.

23. Yamaoka, K., T. Nakagawa, and T. Uno. 1978. Application of Akaike's information criterion (AIC) in the evaluation of linear pharmacokinetic equations. J. Pharmacokinet. Biopharm. 6: 165-175.

Received for publication 14 August 2001 